Article

\title{
Pro-Environmental Behaviours at Work: The Interactive Role of Norms and Attitudinal Ambivalence
}

\author{
Carla Mouro ${ }^{1, *(\mathbb{D})}$, Vera Lomba ${ }^{1}$ and Ana Patrícia Duarte ${ }^{2} \mathbb{D}$ \\ 1 Centro de Investigação e Intervenção Social, Iscte Instituto Universitário de Lisboa, 1649-026 Lisboa, Portugal; \\ veraluislomba@gmail.com \\ 2 Business Research Unit, Iscte Instituto Universitário de Lisboa, 1649-026 Lisboa, Portugal; \\ patricia.duarte@iscte-iul.pt \\ * Correspondence: carla.mouro@iscte-iul.pt
}

check for updates

Citation: Mouro, C.; Lomba, V.; Duarte, A.P. Pro-Environmental Behaviours at Work: The Interactive Role of Norms and Attitudinal Ambivalence. Sustainability 2021, 13, 12003. https://doi.org/10.3390/ su132112003

Academic Editor: Hyo Sun Jung

Received: 23 September 2021

Accepted: 27 October 2021

Published: 29 October 2021

Publisher's Note: MDPI stays neutral with regard to jurisdictional claims in published maps and institutional affiliations.

Copyright: (c) 2021 by the authors. Licensee MDPI, Basel, Switzerland. This article is an open access article distributed under the terms and conditions of the Creative Commons Attribution (CC BY) license (https:// creativecommons.org/licenses/by/ $4.0 /)$.

\begin{abstract}
The environmental costs arising from unsustainable production patterns have increased to the point that organisations are now expected to adopt more responsible practices. Pro-environmental behaviours (PEBs) in the workplace can significantly contribute to bettering companies' environmental performance and sustainability transition. This research investigated the interactive role of norms and attitudes in predicting voluntary energy conservation behaviours, based on a correlational study of 189 Portuguese workers. The study examined whether perceived norm conflicts involving co-workers, closer colleagues and leaders' behaviours promote or hinder workers' own PEBs and whether attitudinal ambivalence towards their organisation's pro-environmental initiatives is a moderator of this relationship. Controlling for the effect of the pro-environmental organisational climate, the ages of employees and organisation size, the results confirm that felt ambivalence moderates the relationship between norm conflict and reported energy conservation behaviours. The findings indicate that ambivalent workers are less likely to engage in PEBs if they perceive norm conflict, that is, if other staff members are not equally motivated to adopt those behaviours. Conversely, norm conflict had an energising effect on non-ambivalent workers. The results thus indicate that organisations could benefit from promoting their environmental policies more explicitly, encouraging their employees to discuss these initiatives and making voluntary PEBs more visible in the workplace.
\end{abstract}

Keywords: pro-environmental behaviours; energy conservation; organisational climate; descriptive norms; norm conflict; attitudinal ambivalence; workplace

\section{Introduction}

The environmental, economic and social costs arising from unsustainable patterns of production and consumption have increased to the point that organisations are now under pressure to adopt more responsible and sustainable practices. Many companies have implemented initiatives that reduce their operations' environmental impacts and contribute to protecting the environment as part of their social responsibility and sustainability policies [1-3]. Pro-environmental behaviours (PEBs) in the workplace have increasingly attracted attention as these can significantly contribute to the improvement of an organisations' environmental performance and their transition to more sustainable operations.

PEBs consist of actions that have a beneficial effect or minimise the detrimental effects on the environment. In the workplace, these behaviours can be integrated into job functions (i.e., proscribed PEBs) or be only informally encouraged (i.e., voluntary PEBs) [4,5]. The present study focused on voluntary actions as these account for most environmentally friendly behaviours at work [6].

Voluntary PEBs include resource and energy conservation behaviours such as separating materials for recycling or turning off lights $[7,8]$. Reducing energy consumption is an important area in which organisations can improve their efficiency. Governments worldwide have defined ambitious policies to encourage more competitive, sustainable 
and secure energy use (e.g., [9,10]), including national goals to reduce energy consumption by $25 \%$ to $35 \%$ by 2050 . Workers can adopt energy conservation behaviours that have a positive impact on their organisation's environmental performance and sustainability [7,11]. A fuller understanding of the barriers to and the facilitators of employees' energy conservation behaviours is thus a critical component of a successful response to this challenge [5,12-14].

Energy conservation behaviours and other PEBs have been studied in domestic contexts (e.g., [15]), but workplace PEBs do not necessarily have the same predictors $[4,16,17]$. Work environments may present not only additional barriers, such as less autonomy in choosing behaviours or a lack of active interest, but also additional facilitators, such as pressure from colleagues to conserve energy [7]. Previous research on energy conservation behaviours in organisations has highlighted the predictive role of individual factors (e.g., attitudes) [8,12,14,18], relational factors (e.g., social norms) [7,13,19] and institutional factors (e.g., organisational climate) [18-22]. However, interactions between these factors have been explored relatively rarely by researchers.

The present study examines how the link between social norms and employees' voluntary PEBs can be moderated by workers' attitudes towards their organisation's pro-environmental climate. These theoretical connections were tested to determine the usefulness of conceptual models that capture the complexity of these psychosocial processes and thus contribute to a better understanding of the relational dynamics promoting more sustainable workplaces $[4,5]$.

\subsection{Social Norms and Workplace PEBs}

A large body of research has confirmed the significant role of social norms in predicting PEBs, including energy conservation behaviours [23-25]. The effects of these norms are based on what individuals consider to be appropriate and normal in a given context [23-25]. Cialdini et al. $[23,24]$ were the first to make a distinction between types of social norms by differentiating between injunctive norms - what other people approve of - and descriptive norms-what other people do. Subsequent research has demonstrated that these two sets of norms can have both an independent and interactive influence on behaviours [26-28].

In organisational contexts, injunctive and descriptive norms correspond with the components of the organisational climate [29], that is, how workers perceive their organisation's formal policies and practices and the behavioural patterns these employees usually observe among other staff members [30,31]. Building on Cialdini et al.'s distinction, Norton et al. [29,32] proposed that the organisational climate's more formal, institutional components can be equated with injunctive norms. For these norms, the organisation functions as a referent for workers, defining how and which environmental concerns are important to their on-the-job performance. Descriptive norms correspond instead to staff members' usual behaviours in the workplace.

Norton et al.'s findings suggest that the organisational climate is linked to taskrelated PEBs, while descriptive norms are associated with voluntary PEBs [32]. The energy conservation behaviours examined in the present study fall into this second category, that is, they are not actions required by regular job functions. These behaviours are thus most likely to be determined by perceived descriptive norms [6]. However, both types of norms were considered in this empirical research, given that other studies have reported a positive link between a pro-environmental organisational climate and workplace PEBs in general (e.g., [33,34]). Moreover, each normative component can also have a different weight depending on the type of PEB under study [35].

In addition, previous research on social norms has often not considered the frequent exposure of individuals to the norms of various groups or the possibility that these norms are unaligned [36,37]. Communities and organisations are frequently composed of multiple groups and referents, some of whom will adopt the targeted behaviours more fully than others do. Neighbours, friends and family or, in the workplace, leaders, co-workers and closer colleagues can thus adopt conservation behaviours to a different extent, making 
the normative direction less obvious to observers. The consequences of norm conflicts or misalignments can be demotivation and fewer PEBs [38,39], which become more probable when individuals feel less committed to the issues at stake, namely, when their attitudes are weaker [38].

However, the literature reports that norm conflict has mixed effects, specifying that misaligned norms can in some cases have an energising or encouraging effect [36]. For instance, employees may perceive co-workers as fully engaged in turning off the lights and equipment but supervisors as not committed to these efforts. This norm conflict can generate a need to compensate for those who fail to engage in PEBs, especially if employees agree with their organisation's efforts to reduce negative impacts on the environment [36]. In an educational context, Smyth et al. [37] showed that perceived norm conflicts between students and teachers led some students to distance themselves from the misalignment by sticking to what is expected of a 'good' student.

The current study thus examines the role of norm conflict between co-workers, closer colleagues and leaders' descriptive norms in predicting energy conservation behaviours. Misalignments between descriptive norms were expected to affect workers' engagement in PEBs, but the direction of impact could depend on the referent groups' perceived levels of engagement in conservation behaviours [38,39]. For moderate to high levels of PEBs adopted by other staff members, norm conflict might cause employees to feel that not everyone has taken action. This perception makes their own behaviour especially important, thereby encouraging conservation behaviours. Given low levels of PEB adoption among other staff members, norm conflict could, however, lead workers to believe that most staff members are not being proactive. Thus, their own actions will not make any difference, thereby demotivating these employees.

The first hypothesis formulated for the present research states:

Hypothesis 1 (H1). Norm conflict is associated with workers' adoption of energy conservation behaviours.

This relationship's direction depends on other staff members' perceived engagement in PEBs. A positive relationship was expected for moderate to high levels of descriptive norms, while a negative link would probably be associated with lower levels of descriptive norms.

\subsection{Attitudinal Ambivalence as a Moderator}

Attitudinal ambivalence occurs when individuals simultaneously have positive and negative beliefs or feelings towards an object, person or situation [40]. Felt ambivalence is often defined as feeling torn between two positions [41], which can be considered a normal characteristic of human meaning-making systems [42,43], but felt ambivalence can imply discomfort and delays regarding making decisions and taking action [44]. Ambivalence has thus been seen as a barrier to engagement [45] and as needing to be resolved rapidly. However, the literature also highlights the positive aspects of ambivalent attitudes, such as a stronger engagement in deep pondering [46,47] and exposure to unfamiliar information [48]. Both sides of ambivalence are not incompatible, although they indicate, especially for controversial subjects $[49,50]$, that individuals may go through more elaborate meaning-making processes that delay action [45], so ambivalence can be a potential barrier to workers' adoption of PEBs on the job. The current research sought to clarify whether and under which conditions this negative effect can happen.

This study considered the potential ambivalence felt towards organisations' investment in pro-environmental policies and practices. In other words, the research focused on employees' felt ambivalence regarding their organisation's pro-environmental climate. Leaders' expressed ambivalence or ambiguity has been found to be a significant source of task disengagement $[37,51]$, but workers' ambivalence towards organisational policies has rarely been examined in this context [49]. Perceptions of the organisational climate have a positive link with workers' adoption of voluntary PEBs [8,18-20], yet no research has yet examined whether having mixed feelings about institutional-level policies and practices could hinder the adoption of PEBs by employees in the workplace. The barrier 
effect of ambivalence could be due to workers' uncertainty about the positive effects of their organisation's investment in pro-environmental initiatives such as environmental education projects or water and energy conservation measures.

A literature review conducted for the present study confirmed that this approach has not been previously applied, although previous studies have concentrated on the role of ambivalence in other organisational domains (e.g., safety behaviours [49,52] and organisational identification [53-55]). The current research sought to contribute to the extant literature by exploring how ambivalence is intertwined with norms at both the institutional and relational levels [50] of work contexts. The present study evaluated levels of ambivalence regarding institutional norms (i.e., the pro-environmental organisational climate) and looked at the ways this ambivalence interacts with perceived norms to predict individuals' behaviours within their organisation.

More concretely, this research examined whether workers' ambivalent attitudes towards their organisations can moderate the relationship between group norms and PEBs. The mixed feelings of employees about their organisation's pro-environmental climate probably stem from perceived discrepancies between these individuals' personal goals and values and those of their organisation [56-58]. This reduced confidence in how much they should support their organisation's policies could lead workers to be more open to other contextual and interactional clues, especially counter-normative ones, such as the inconsistent levels of engagement in PEBs from colleagues and leaders. The potential misalignment of other workers' PEBs can thus become a significant demotivator of these behaviours' adoption at work [36].

Conversely, the adoption of PEBs by non-ambivalent workers may be less negatively affected by other staff members' conflicts or misalignment with regard to these behaviours. As stated in the previous section, an energising effect could be associated with a lack of consistency in relation to norms [38]. Non-ambivalent employees would be more likely to act according to their own goals and motivations [38] and less likely to be affected by negative contextual cues [39,50].

In summary, experiencing ambivalence towards their organisation's pro-environmental climate can lead employees to be more attentive to other contextual cues when deciding whether to adopt PEBs. The negative effects of norm conflict on the reported PEBs will be stronger among ambivalent employees as stated in the present study's second hypothesis:

Hypothesis 2 (H2). Attitudinal ambivalence towards the pro-environmental organisational climate moderates the relationship between norm conflict and workers' energy conservation behaviours.

The negative link between norm conflict and PEBs will thus be reinforced for ambivalent employees as compared to unambivalent ones.

\section{Materials and Methods}

The following subsections provide detailed information about this study's participants, data collection procedures and survey measures.

\subsection{Participants and Procedures}

A total of 189 employees voluntarily filled in this study's online survey, which was distributed in 2016 and 2017. All the respondents had Portuguese nationality and their ages ranged from 20 to 66 years old (mean $=37.3$; standard deviation $[S D]=10.7$ ). Most participants were females $(58.7 \%)$ with a university degree $(70.9 \%)$. More than two-thirds worked at for-profit organisations $(68.6 \%)$, while the remaining respondents worked for non-profits $(31.4 \%)$. Most participants worked for private organisations $(72.9 \%)$, while less than one-third worked for public entities $(27.1 \%)$. The sizes of the organisations were categorised as micro (up to 9 workers, $11.7 \%$ ), small (10-49 workers, $17.0 \%$ ), medium-sized (50-249 workers, $25.0 \%)$, large (250-500 workers, $12.8 \%$ ) and extremely large (more than 500 workers, $33.5 \%)$. These companies operated primarily in the tertiary sector (88.6\%). 
To guarantee that the respondents had had sufficient contact with their organisation's policies and practices, all the participants had to have worked for at least one year in their current organisation. Overall, these workers had a mean tenure of 10.1 years (minimum $[\mathrm{min}]=1$; maximum $[\max ]=40$ ), while $68.8 \%$ had a permanent employment contract and $21.2 \%$ were in management positions.

The research had a cross-sectional correlational design and used non-probability convenience sampling. $\mathrm{G}^{*}$ Power software was used to calculate the ideal sample size based on its statistical power [59] and to certify the collected sample's adequacy. A sample size of 129 was recommended to achieve a statistical power of 0.95 in the model-testing phase. Since the present study's sample size exceeded this number, it was deemed sufficiently large enough to test the research model.

The respondents were recruited via social media and invited to fill in a questionnaire made available online using Qualtrics Surveys software. The study followed the ethical standards guidelines of Portugal's Order of Psychologists. All the participants were informed of the confidentiality and anonymity of their responses. After giving their informed consent, the respondents scored the items measuring the main variables selected, as well as answering questions about their professional and socio-demographic characteristics. The participants were then debriefed and provided further information about the study's purpose.

\subsection{Measures}

The questionnaire included the following measures selected from the existing literature on relevant topics.

\subsubsection{Pro-Environmental Organisational Climate}

Five items adapted from Duarte [60], Norton et al. [32] and Turker's [61] scales assessed the perceptions of organisational policies and practices focused on environmental sustainability. Responses were given on a five-point scale ranging from 1 for 'totally disagree' to 5 for 'totally agree'. The items evaluated how much the respondent's organisation 'tries to reduce its impact on the environment', 'tries to reduce the amount of natural resources used during its operations (e.g., water and energy)', 'collaborates in environmental education projects', ' gives donations to associations protecting the environment' and 'upholds the importance of protecting the environment'. The five-item scale presents high internal consistency (Cronbach's alpha $[\alpha]=0.81$ ), and the responses of each item were averaged into a single score.

\subsubsection{Descriptive Norms}

Descriptive norms were assessed using six items adapted from Carrico and Riemer [7] and Gökeritz et al.'s [26] studies. The two selected energy conservation behaviours were evaluated regarding three referents. That is, the respondents rated three different referents separately, specifically, how many of their co-workers, closer colleagues and leaders 'turn off the lights when they leave a room' and 'shut down equipment after using it'. The responses were given on a scale ranging from 1 for 'no one' to 5 for 'all'. A high internal consistency $(\alpha=0.90)$ was obtained for this measure, and an overall descriptive norm score was computed.

\subsubsection{Norm Conflict}

An index of descriptive norm conflict was estimated using the formula $A B S(X-Y)$ to assess how different the three referents' descriptive norms were, as suggested by McDonald et al. [38]. The mean scores found for each referent were as follows: coworkers (mean $=3.46 ; \mathrm{SD}=0.83$ ), closer colleagues (mean $=3.59 ; \mathrm{SD}=0.90$ ) and leaders (mean $=3.55 ; \mathrm{SD}=0.96)$. The complete formula is presented below in Equation (1):

mean $\left[a b s\left(\right.\right.$ Norm $_{\text {coworkers }}-$ Norm $\left._{\text {colleagues }}\right)+a b s\left(\right.$ Norm $_{\text {coworkers }}-$ Norm $\left._{\text {leaders }}\right)+a b s\left(\right.$ Norm $_{\text {colleagues }}-$ Norm $\left.\left._{\text {leaders }}\right)\right]$ 
The possible range of conflict values was set between 0 for 'no conflict' and 12 for 'high conflict'. The values found for the sample ranged from 0 to 6 (mean $=1.13 ; \mathrm{SD}=1.25$ ).

\subsubsection{Attitude towards the Pro-Environmental Organisational Climate}

The attitude measure was adapted from Poortinga and Pidgeon's [62] and Mouro and Castro's [50] research. Respondents were asked to choose one option out of four choices that best described their position regarding their organisation's pro-environmental initiatives. The options were 'I support these initiatives' (positive attitude), 'I do not support these initiatives' (negative attitude), 'I think good reasons exist for both supporting and contesting these initiatives' (ambivalent attitude) and 'I don't care whether my organisation implements these initiatives or not' (indifferent attitude). The respondents' choices were related to the four initiatives included in the aforementioned pro-environmental climate measure (e.g., 'my organisation tries to reduce its impact on the environment').

Table 1 presents the percentages for each of the four possible responses for the different initiatives. Overall, most participants chose the positive attitude position $(\mathrm{min}=71.4 \%$; $\max =94.7 \%)$, followed by the ambivalent $(\min =6.1 \%$; $\max =18.5 \%)$, indifferent $(\mathrm{min}=1.6 \%$; $\max =7.4 \%$ ) and negative positions $(\min =0.0 \% ; \max =2.6 \%)$. In subsequent analyses, all the respondents who selected the ambivalent option for one or more of the initiatives were considered to be 'ambivalent' workers (23.8\%, score 1$)$, and all other participants were considered to be 'non-ambivalent' workers $(76.2 \%$, score 0$)$.

Table 1. Attitudes towards the Pro-environmental Organisational Climate Initiatives.

\begin{tabular}{|c|c|c|c|c|}
\hline & $\begin{array}{l}\text { Positive } \\
\text { Attitude }\end{array}$ & $\begin{array}{l}\text { Negative } \\
\text { Attitude }\end{array}$ & $\begin{array}{c}\text { Indifferent } \\
\text { Attitude }\end{array}$ & $\begin{array}{c}\text { Ambivalent } \\
\text { Attitude }\end{array}$ \\
\hline \multirow{5}{*}{$\begin{array}{l}\text { My organisation ... } \\
\ldots \text { tries to reduce its impact on the environment. } \\
\ldots \text { tries to reduce the amount of natural resources } \\
\text { used during its operations (e.g., water and energy). } \\
\ldots \text { collaborates in environmental education projects. } \\
\ldots \text { makes donations to associations that seek to } \\
\text { protect the environment. }\end{array}$} & & & & \\
\hline & $94.7 \%$ & - & $3.2 \%$ & $2.1 \%$ \\
\hline & $91.5 \%$ & - & $1.6 \%$ & $6.9 \%$ \\
\hline & $87.8 \%$ & $1.1 \%$ & $4.2 \%$ & $6.9 \%$ \\
\hline & $71.4 \%$ & $2.6 \%$ & $7.4 \%$ & $18.5 \%$ \\
\hline
\end{tabular}

\subsubsection{Energy Conservation Behaviours}

The two items that measured energy conservation behaviours were based on Greaves et al. [63] and Robertson and Barling's [64] studies. Responses about the frequency of 'turning off the lights when leaving a room' and 'shutting down equipment after using it' were collected on a scale ranging from 1 for 'never' to 5 for 'very frequently'. The answers to the two items presented a moderate positive correlation $(r=0.35 ; p<0.001)$.

\subsection{Common Method Bias}

Common method bias results from collecting data from the same source for all variables. In the present study, the risk of potential bias was reduced by using different rating scales [65]. Bias was also controlled for by carrying out an unrotated principal component analysis of all the items included in the research model to measure the main variables. The results show that the first factor explains $37.8 \%$ of the variability observed (total variance explained $=73.3 \%$; Kaiser-Meyer-Olkin $=0.81 ; p<0.00)$, indicating that the adopted measures pass Harman's single factor test [65]. Thus, common method variance does not significantly weaken the validity of the findings or distort the interpretations of the results.

\section{Results}

All analyses were conducted using IBM SPSS Statistics Version 26 software. Table 2 presents the descriptive statistics and intercorrelations among the research model's variables and the respondents' socio-professional characteristics. On average, the workers surveyed perceived their organisation as being moderately engaged in implementing pro- 
environmental policies and practices (mean $=3.31 ; \mathrm{SD}=0.79)$ and some other employees as adopting energy conservation behaviours in the workplace (mean $=3.53 ; \mathrm{SD}=0.82$ ). The level of norm conflict found was low (mean $=1.13$; $\mathrm{SD}=1.25$ ), suggesting a similar perceived engagement in energy conservation behaviours among the three referents. However, as mentioned previously (see Section 2.2.3), co-workers were seen as being less proactive than closer colleagues and leaders. The participants also reported having high levels of energy conservation behaviours at work (mean $=4.71 ; \mathrm{SD}=0.73$ ).

Table 2. Descriptive statistics and correlations for variables (number $=189$ ).

\begin{tabular}{|c|c|c|c|c|c|c|c|c|}
\hline & $\mathbf{M}$ & SD & 1 & 2 & 3 & 4 & 5 & 6 \\
\hline 1. Age & 37.35 & 10.71 & & & & & & \\
\hline 2. Organisation size ${ }^{1}$ & - & - & -0.10 & & & & & \\
\hline 3. Organisational climate & 3.31 & 0.79 & $0.21^{* *}$ & 0.11 & & & & \\
\hline 4. Descriptive norm & 3.53 & 0.82 & $0.23 * *$ & $-0.23 * *$ & $0.29 * *$ & & & \\
\hline 5. Norm conflict & 1.13 & 1.25 & -0.60 & 0.81 & -0.13 & -0.18 * & & \\
\hline 6. Attitudinal ambivalence ${ }^{2}$ & - & - & -0.06 & -0.11 & -0.01 & -0.14 & 0.00 & \\
\hline 7. Energy conservation behaviours & 4.51 & 0.73 & $0.16^{*}$ & $-0.15 *$ & 0.00 & $0.31^{* *}$ & -0.03 & $-0.17^{*}$ \\
\hline
\end{tabular}

Notes: $\mathrm{M}=$ mean; $\mathrm{SD}=$ standard deviation; ${ }^{*} p<0.05 ;{ }^{* *} p<0.01 ;{ }^{1}$ organisation size scored 1 for micro (up to 9 workers), 2 for small (10-49 workers), 3 for medium-sized (50-249 workers), 4 for large (250-500 workers) and 5 for extremely large (more than 500 workers);

2 attitudinal ambivalence scored 0 for 'no' and 1 for 'yes'.

The respondents' gender, education, tenure and management position were not significantly associated with the criteria variable, but age and organisation size were significantly related to energy conservation in the workplace so they were included as covariates in subsequent analyses. The descriptive norm variable was positively correlated with workers' self-reported energy conservation behaviours, while attitudinal ambivalence was negatively related to this variable. Pro-environmental organisational climate and norm conflict were shown to have no significant association with the criteria variable.

The variables' interactive effect was tested for using PROCESS Macro Version 3.5 software's Model 1 [66]. A regression analysis of all the relevant variables had been previously conducted to exclude multicollinearity between variables. Both the tolerance $(\geq 0.81)$ and variance inflation factor $(\mathrm{VIF})$ values $(\leq 1.03)$ complied with the recommended thresholds of no lower than 0.10 for tolerance [67] and no higher than 5.00 for VIF [68].

The present study's first hypothesis predicted that norm conflict would have a significant effect on energy conservation behaviours. The multiple regression analysis confirmed a significant positive effect (non-standardised coefficient $[B]=0.11 ; 95 \% \mathrm{CI}=0.01 ; 0.20$ ) (see Table 3), which is in alignment with the moderate level of descriptive norms found for the sample (see Table 2 above). This result indicates that the higher the misalignment between perceived descriptive norms in the workplace (i.e., among co-workers, closer colleagues and leaders), the more common reported energy conservation behaviours become. Hypothesis 1 was thus supported by the data.

The effect of norm conflict occurs when considering also the overall impact of the descriptive norms, which was included as a covariate in the analyses. Descriptive norms were also found to have a significant effect $(B=0.25 ; 95 \%$ confidence interval $[\mathrm{CI}]=0.12 ; 0.38)$ on PEBs. This finding suggests that the more employees believe others in their organisation are adopting energy conservation behaviours, the more likely workers are to report engaging in these behaviours themselves. Pro-environmental climate and ambivalence towards organisational climate have no significant direct effect on energy conservation behaviours.

The second hypothesis focused on how the interactive effect between norm conflict and attitudinal ambivalence affects energy saving behaviours. More concretely, workers' ambivalent feelings about their organisation's pro-environmental policies and practices were expected to reinforce the effect of norm conflict, whereas non-ambivalent employees would not be-or be less-affected by norm conflict compared to ambivalent respondents. The results confirm that a significant interaction exists between norm conflict and ambivalence $\left(B=-0.34 ; \Delta R^{2}=0.06 ; p<0.000\right)$ (see Table 2 above). The conditional interactive effect 
detected verifies that ambivalence has the expected moderating role in reinforcing the negative effect of norm conflict on energy conservation behaviours $(B=-0.23 ; 95 \% \mathrm{CI}=-0.39$, $-0.08)$. The reverse effect was found for non-ambivalent workers, for whom the impact of norm conflict on energy conservation was positive $(B=0.11 ; 95 \% \mathrm{CI}=0.01,0.20)$ (see Figure 1). Hypothesis 2 was thus confirmed. The results indicate that the ambivalence of employees about their organisation's pro-environmental climate plays a significant role in how they make sense of other staff members' PEBs and decide how to act. The model overall explains $19 \%$ of the variance in workers' energy conservation behaviours at work $(F[7,180]=5.96 ; p<0.000)$.

Table 3. Regression results for attitudinal ambivalence's moderation effect on the relationship between norm conflict and energy conservation behaviours.

\begin{tabular}{|c|c|c|c|}
\hline \multirow[t]{2}{*}{ Variables } & \multicolumn{3}{|c|}{ Workplace Energy Conservation Behaviours } \\
\hline & $B$ & LLCI & ULCI \\
\hline Constant & $3.85^{* *}$ & 3.19 & 4.50 \\
\hline Age & 0.01 & -0.00 & 0.02 \\
\hline Organisation size $^{1}$ & -0.04 & -0.11 & 0.03 \\
\hline Pro-environmental organisational climate & -0.08 & -0.21 & 0.05 \\
\hline Descriptive norm & $0.25 * *$ & 0.12 & 0.38 \\
\hline Norm conflict & $0.11 *$ & 0.01 & 0.20 \\
\hline Attitudinal ambivalence ${ }^{2}$ & -0.22 & -0.45 & 0.01 \\
\hline Interaction norm conflict $\mathrm{x}$ ambivalence & $-0.34^{* *}$ & -0.52 & -0.16 \\
\hline & \multicolumn{3}{|c|}{$\begin{aligned} R^{2} & =0.19 ; F(7,180)=5.96 ; p<0.000 \\
\Delta R^{2} & =0.06 ; F(1,180)=13.59 ; p<0.000\end{aligned}$} \\
\hline Conditional Effects & Effect & LLCI & ULCI \\
\hline Non-ambivalent & $0.11 *$ & 0.01 & 0.20 \\
\hline Ambivalent & $-0.23^{* *}$ & -0.39 & -0.08 \\
\hline
\end{tabular}

Notes: $B=$ non-standardised coefficient; LLCI $=$ lower limit confidence interval; ULCI $=$ upper limit confidence interval; ${ }^{*} p<0.05$; ** $p<0.01 ;{ }^{1}$ organisation size scored 1 for micro (up to 9 workers), 2 for small (10-49 workers), 3 for medium-sized (50-249 workers), 4 for large (250-500 workers) and 5 for extremely large (more than 500 workers); ${ }^{2}$ attitudinal ambivalence scored 0 for 'no' and 1 for 'yes'; $R^{2}=$ coefficient of determination; $F=$ ratio of two variances; $\Delta R^{2}=$ change in $R^{2}$ between two calculations.

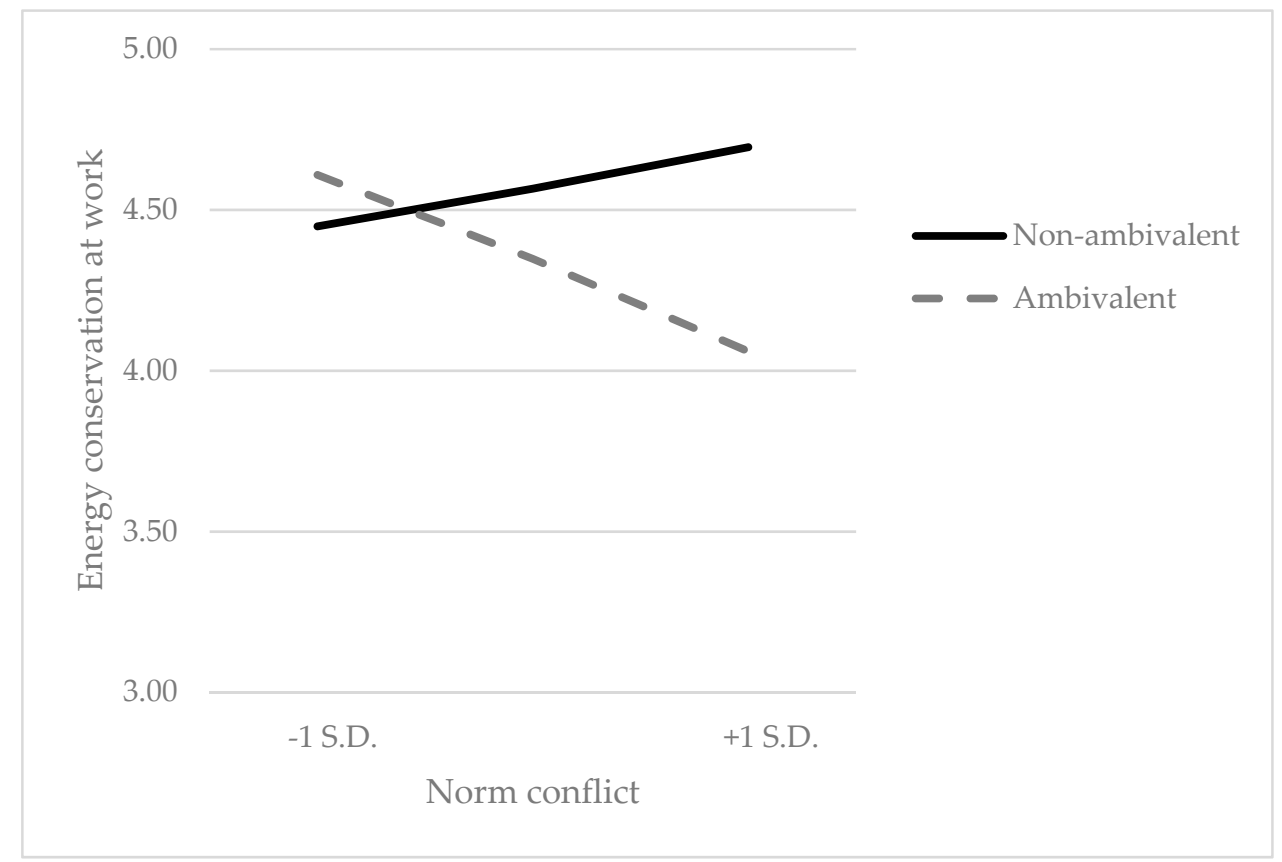

Figure 1. The interactive effect of norm conflict and ambivalence on energy conservation at work. 


\section{Discussion}

Organisations' environmental performance has increasingly come under scrutiny as societies are beginning to realise just how imperative the rapid achievement of more sustainable production and consumption patterns has become. This movement towards a greener, carbon-free economy presents various challenges, including energy management. Combined with technological innovations that enhance energy efficiency (e.g., light emitting diode lamps), employees' PEBs are essential to organisations' efforts to achieve their desired goals $[9,10,14]$. The present study specifically focused on examining the interactive role of norms and attitudes as predictors of individuals' energy conservation behaviours in the workplace because these can contribute to improving organisations' environmental performance and sustainability $[5,69,70]$.

The current research's finding confirm the role of attitudes and social norms in encouraging employees' voluntary PEBs and extend the existing literature by highlighting the added value of taking the interplay between these factors into consideration. The first hypothesis was supported by evidence of a significant association between norm conflict and reported energy conservation behaviours. Consistent with previous research [36], the degree of misalignment between the norms of different groups is associated with stronger engagement in PEBs. McDonald et al. [36] found that misaligned household and community descriptive norms were associated with reduced water consumption, which indicates that norm conflict sometimes has a motivating effect.

In the present study, the positive effect of norm conflict appeared to be associated with the employees' perception that co-workers, closer colleagues and leaders had already adopted energy conservation behaviours to a moderate degree. Consequently, the workers' own behaviour would significantly add to their organisation's positive pro-environmental climate. These findings may also suggest that staff members decide to act depending on the perceived effectiveness of their behaviours in terms of reducing energy consumption's environmental impact [36]. Further research could explore the potential mediating effect of this perceived effectiveness on work contexts and clarify whether the process is activated by the level of engagement of referent groups in PEBs.

Another potential line of research would be to examine the impact of different referents in terms of the magnitude of the effect of norm conflict on employees' behaviours. In other words, future studies could explore whether the deviant behaviour of co-workers or leaders is more closely related to the promotion or to the impedance of workers' own behaviour. This additional research could also contribute to a better understanding of the implications of some referents included in norm conflict studies who comprise nested groups [36,38]. For example, households are part of communities, and leaders can also be considered co-workers. The consequences of this overlapping for the prevalence of norm conflict should be more thoroughly investigated.

Identification can also play a role in how norm conflicts affect behaviours. High identifiers within groups appear to disengage from conflicting normative influences by following norms for being a 'good' student [37] or worker. Along these lines, previous research has shown that a strong commitment to being a pro-environmental worker is a robust predictor of PEBs $[19,20]$. Future studies could further explore the implications of identity processes, as well as exploring whether organisational identification is a significant moderator of how norm conflicts influence PEBs in the workplace.

The present research also found, when testing the full model, that descriptive norms but not organisations' pro-environmental climate-has a significant association with PEBs. The literature includes divergent findings, with some studies providing evidence that voluntary PEBs can be predicted more accurately by descriptive norms $[6,29]$ while other investigations have found evidence that prescriptive components are also important $[19,20]$. The current results indicate that, for voluntary energy conservation behaviours, descriptive norms are more significant than the pro-environmental organisational climate is. Further research could concentrate on disentangling which sources of influence are most strongly associated with different types of voluntary PEBs [35]. 
The present study's second hypothesis posited that workers' feelings of ambivalence towards their organisation's pro-environmental climate reinforce negative relationships between norm conflict and voluntary energy conservation behaviours at work. This hypothesis was corroborated by evidence of norm conflict's negative effect on PEBs among ambivalent workers, while, for non-ambivalent employees, norm conflict had a positive impact. These findings indicate that, when workers' attitudes towards environmental practices and policies are unclear, the realisation that other staff members are not equally motivated to adopt PEBs makes these ambivalent workers less inclined to adopt these behaviours. When employees' attitudes are unidirectional and non-ambivalent, norm conflict appears to have an energising effect.

These results are in line with previous research on the interactive effect of attitudes and social norms [36-39]. McDonald et al. [38] confirmed that the effect of perceived norm conflicts between neighbours, friends and communities is stronger for residents with a less positive attitude towards species conservation, which contributes to fewer pro-conservation behaviours. Conversely, residents with a strong positive attitude are unaffected by norm conflict. The current research adds to the existing literature by showing that not only an attitude's strength but also its ambivalent nature can affect the impact of norm conflict.

These findings thus suggest that ambivalence may lead workers to pay more attention to contextual counter-normative cues and interpret them in ways that discourage proenvironmental actions [45-47]. When attitudes are univalent, a strong commitment to environmental causes instead leads employees to read contextual cues as reinforcing the need to 'do the right thing' [36,38]. The current study thus contributes to the clarification of the psychosocial processes through which organisations' sustainability policies and co-workers' behaviours affect workplace PEBs. Further research is needed to confirm the stability of these results across the full scope of PEBs, as well as in other domains of organisational life, such as safety behaviours [49].

\subsection{Limitations and Future Research}

Despite the significant findings reported above, this study had limitations that must be considered when interpreting and generalising its results. One set of limitations has to do with the cross-sectional correlational design, which not only restricted the possibility of drawing clear conclusions about causality between variables but also increased the risk of spurious covariance between variables. Preventative measures were taken to reduce potential common method bias, including using different response scales, protecting anonymity and diminishing evaluation apprehension via the survey's instructions [65]. Harman's single factor test was also performed to assess the first factor's dominance, which indicated that, even though the data were collected at the same time from the same source, common method bias was not a serious problem in the results. However, future research could adopt more empirically robust research designs to address these limitations, for example, conducting longitudinal studies or collecting data at different points in time.

In addition, the data were self-reported by workers, including their energy conservation behaviours. Previous research has confirmed that social desirability has a small to nonsignificant effect on the way individuals report their PEBs in anonymous surveys [71], such as the one used in this study. Nevertheless, researchers may want to use more diversified sources of information, for instance, collecting data about people's behaviour from closer colleagues or relevant leaders.

Other limitations have to do with the non-probabilistic convenience sampling approach used to recruit respondents. The sample included workers from varied organisations and business sectors, but its non-probabilistic nature limits the generalisability of the findings to the general research population (i.e., all Portuguese employees). Further studies could use larger, more representative samples to ensure the evidence for the relationships identified is reliable.

Based on the convenience sample, this research was able to examine energy conservation behaviours found across different organisations. Future investigations may 
obtain other results by collecting data from more delimitated contexts, such as specific business sectors, organisations or even various workspaces within a given organisation. The voluntary PEBs covered by the present study (i.e., turning off lights and shutting down equipment) might tend to occur more in some contexts (e.g., offices) than in others (e.g., production lines). More context-specific analyses could identify conservation behaviours restricted to particular contexts, thereby guiding customised interventions focused on increasing PEBs in those places.

The behaviours analysed here were directly enacted by individuals, but workers can also engage in indirect green behaviours, such as actions that influence others to be more eco-friendly at work [72]. Indirect behaviours can be incorporated into research models, including, among others, advocating resource-saving behaviours to colleagues, in order to carry out more thorough analyses of workplace PEBs. This approach is especially important as individuals' motivations for engaging in different types of behaviours could vary significantly $[35,73]$.

\subsection{Practical Implications}

The current findings have implications for organisations that want to improve their environmental performance in term of energy conservation, as well as in other areas. Organisations need to focus on promoting a closer alignment between different group members' PEBs in daily activities (e.g., leaders, co-workers and closer colleagues) to reduce perceived norm conflict. This strategy is especially important when organisational policies and practices generate controversy as can be the case for some pro-environmental initiatives. Implementing green human resource management practices and fostering responsible leadership is one way for organisations to demonstrate their commitment to environmental conservation, with potential positive effects on individuals' PEBs [69,70]. In addition, management should take into account that energy conservation behaviours can be considered low intensity behaviours that do not require much effort from workers and organisations. However, these behaviours are also characterised by low visibility [13]. Thus, eliciting feedback from employees could help raise the profile of co-workers' energy saving behaviours (e.g., $[7,74])$.

Reducing workers' attitudinal ambivalence towards organisations' environmental practices is another important strategy that ensures workers will not be demotivated if they perceive their co-workers as not all equally engaged in eco-friendly practices. The present findings suggest that investing in reducing ambivalence towards a pro-environmental climate can pay off in the form of workers' stronger commitment to reducing energy waste. Although employees' energy conservation behaviours and other PEBs at work may appear to be insignificant when taken individually, they can have a multiplier effect when they are mimicked by other staff members [75]. All workers can contribute significantly to meeting the challenge of achieving more environmentally efficient and sustainable organisations.

Interventions to reduce ambivalent attitudes need to be carefully planned. Some authors have reported that ambivalence can help individuals to resist undue social influence [76]. Changes inspired by organisational initiatives may thus be superficial and of limited duration among ambivalent workers, especially if they perceive remaining ambivalent as a valued form of self-presentation $[77,78]$. This lack of sustainability can be particularly evident with regard to controversial issues [77], including organisations' investment in non-profitable pro-environmental activities. Notably, research on corporate social responsibility has shown that environmental initiatives are less closely related to employees' job satisfaction and organisational commitment than initiatives targeting organisations' human resources are [2,60,79].

In conclusion, the present results suggest that employees' perception of their organisations' environmental policies and initiatives is a significant factor in how these workers evaluate what happens with other staff members on the job. Employees may engage in more voluntary PEBs if they think other members are not aligned in their behaviours, yet, if they have mixed feelings towards their organisation's policies, misalignments between 
other members' behaviours instead becomes a demotivator. Organisations need to invest in making their choices clearer to generate more consensus around policies and to incentivise workers' involvement in environmental causes such as supporting nature conservation projects or reducing energy consumption.

Although norm conflict and attitudinal ambivalence are common phenomena, these variables have received limited attention from researchers who focus on organisational dynamics. In this context, the present study's examination of these psychosocial processes provides a fuller understanding of employees' responses to institutional pro-environmental policies.

Author Contributions: Conceptualisation, methodology, and supervision, C.M. and A.P.D.; investigation, and formal analysis, C.M., V.L. and A.P.D.; writing-original draft preparation, C.M., A.P.D. and V.L.; writing-review and editing, C.M. and A.P.D.; project administration, C.M. All authors have read and agreed to the published version of the manuscript.

Funding: This research was partially supported by Portugal's Fundação para a Ciência e Tecnologia [Grants UIDB/00315/2020, UID/PSI/03125/2013 and UID/03125/2020 and contracts DL 57/2016/CP1359/CT0006 and DL 57/2016/CP1359/CT0004].

Institutional Review Board Statement: The study was conducted according to the guidelines of the Declaration of Helsinki.

Informed Consent Statement: Informed consent was obtained from all subjects involved in the study.

Data Availability Statement: Data supporting reported results will be made available by the authors upon request.

Acknowledgments: The authors wish to thank the students who assisted them with the data collection and the participants without whom this study would not have been possible.

Conflicts of Interest: The authors declare no conflict of interest.

\section{References}

1. Dahlmann, F.; Branicki, L.; Brammer, S. Managing carbon aspirations: The influence of corporate climate change targets on environmental performance. J. Bus. Ethics 2019, 158, 1-24. [CrossRef]

2. Duarte, A.P.; Neves, J.G.D.; Gomes, D.R.; Moisés, G.A. Corporate social responsibility, job satisfaction, and customer orientation in Angola. World Rev. Entrepr. Manag. Sustain. Dev. 2019, 15, 93-109. [CrossRef]

3. Tian, Q.; Robertson, J.L. How and when does perceived CSR affect employees' engagement in voluntary pro-environmental behavior? J. Bus. Ethics 2019, 155, 399-412. [CrossRef]

4. Unsworth, K.L.; Davis, M.C.; Russell, S.V.; Bretter, C. Employee green behavior: How organizations can Help the environment. Curr. Opin. Psychol. 2020, 42, 1-6. [CrossRef]

5. Yuriev, A.; Boiral, O.; Francoeur, V.; Paillé, P. Overcoming the barriers to pro-environmental behaviors in the workplace: A systematic review. J. Clean. Prod. 2018, 182, 379-394. [CrossRef]

6. Priyankara, H.P.R.; Luo, F.; Saeed, A.; Nubuor, S.A.; Jayasuriya, M.P.F. How does leader's support for environment promote organizational citizenship behaviour for environment? A multi-theory perspective. Sustainability 2018, 10, 271. [CrossRef]

7. Carrico, A.R.; Riemer, M. Motivating energy conservation in the workplace: An evaluation of the use of group-level feedback and peer education. J. Environ. Psychol. 2011, 31, 1-13. [CrossRef]

8. Blok, V.; Wesselink, R.; Studynka, O.; Kemp, R. Encouraging sustainability in the workplace: A survey on the pro-environmental behaviour of university employees. J. Clean. Prod. 2015, 106, 55-67. [CrossRef]

9. European Commission. Energy 2020-A Strategy for Competitive, Sustainable and Secure Energy. 2011. Available online: https:/ / ec.europa.eu/energy/sites/ener/files/documents/2011_energy2020_en_0.pdf (accessed on 14 September 2021).

10. Portuguese Government. Plano Nacional de Energia e Clima 2021-2030. 2019. Available online: https:/ / ec.europa.eu/ energy/ sites / ener / files / documents /pt_final_necp_main_pt.pdf (accessed on 14 September 2021).

11. Dumitru, A.; De Gregorio, E.; Bonnes, M.; Bonaiuto, M.; Carrus, G.; Garcia-Mira, R.; Maricchiolo, F. Low carbon energy behaviors in the workplace: A qualitative study in Italy and Spain. Energy Res. Soc. Sci. 2016, 13, 49-59. [CrossRef]

12. Canova, L.; Manganelli, A.M. Energy-saving behaviours in workplaces: Application of an extended model of the theory of planned behaviour. Eur. J. Psychiatry 2020, 16, 384-400. [CrossRef]

13. Ciocirlan, C.E.; Gregory-Smith, D.; Manika, D.; Wells, V. Using values, beliefs, and norms to predict conserving behaviors in organizations. Eur. Manag. Rev. 2020, 17, 543-558. [CrossRef]

14. Xu, X.; Xiao, B.; Li, C.Z. Analysis of critical factors and their interactions influencing individual's energy conservation behavior in the workplace: A case study in China. J. Clean. Prod. 2021, 286, 124955. [CrossRef] 
15. Nolan, J.M.; Schultz, P.W.; Cialdini, R.B.; Goldstein, N.J.; Griskevicius, V. Normative social influence is underdetected. Personal. Soc. Psychol. Bull. 2008, 34, 913-923. [CrossRef] [PubMed]

16. Whitmarsh, L.E.; Haggar, P.; Thomas, M. Waste reduction behaviors at home, at work, and on holiday: What influences behavioral consistency across contexts? Front. Psychol. 2018, 9, 2447. [CrossRef]

17. Carrus, G.; Tiberio, L.; Mastandrea, S.; Chokrai, P.; Fritsche, I.; Klöckner, C.A.; Masson, T.; Vesely, S.; Panno, A. Psychological predictors of energy saving behavior: A meta-analytic approach. Front. Psychol. 2021, 12, 648221. [CrossRef] [PubMed]

18. Zhang, Y.; Wang, Z.; Zhou, G. Determinants of employee electricity saving: The role of social benefits, personal benefits and organizational electricity saving climate. J. Clean. Prod. 2014, 66, 280-287. [CrossRef]

19. Mouro, C.; Duarte, A.P. Organisational climate and pro-environmental behaviours at work: The mediating role of personal norms. Front. Psychol. 2021, 168, 4146. [CrossRef]

20. Zhang, Y.; Wang, Z.; Zhou, G. Antecedents of employee electricity saving behavior in organizations: An empirical study based on norm activation model. Energy Policy 2013, 62, 1120-1127. [CrossRef]

21. Wesselink, R.; Blok, V.; Ringersma, J. Pro-environmental behaviour in the workplace and the role of managers and organisation. J. Clean. Prod. 2017, 168, 1679-1687. [CrossRef]

22. Hicklenton, C.; Hine, D.W.; Loi, N.M. Can work climate foster pro-environmental behavior inside and outside of the workplace? PLoS ONE 2019, 14, e0223774. [CrossRef]

23. Cialdini, R.B.; Reno, R.R.; Kallgren, C.A. A focus theory of normative conduct: Recycling the concept of norms to reduce littering in public places. J. Personal. Soc. Psychol. 1990, 58, 1015-1026. [CrossRef]

24. Cialdini, R.B.; Kallgren, C.A.; Reno, R.R. A focus theory of normative conduct: A theoretical refinement and reevaluation of the role of norms in human behavior. In Advances in Experimental Social Psychology; Zanna, M.P., Ed.; Academic Press: Cambridge, MA, USA, 1991; Volume 24, pp. 201-234.

25. McDonald, R.; Crandall, C. Social norms and social influence. Behav. Sci. 2015, 3, 147-151. [CrossRef]

26. Gökeritz, S.; Schultz, P.W.; Rendón, T.; Cialdini, R.B.; Goldstein, N.J.; Griskevicius, V. Descriptive normative beliefs and conservation behavior: The moderating roles of personal involvement and injunctive normative beliefs. Eur. J. Soc. Psychol. 2010, 40,514-523. [CrossRef]

27. Goldstein, N.J.; Cialdini, R.B.; Griskevicius, V. A room with a viewpoint: Using social norms to motivate environmental conservation in hotels. J. Consum. Res. 2008, 35, 472-482. [CrossRef]

28. Plows, S.E.; Smith, F.D.; Smith, J.R.; Chapman, C.M.; La Macchia, S.T.; Louis, W.R. Healthy eating: A beneficial role for perceived norm conflict? J. Appl. Soc. Psychol. 2017, 47, 295-304. [CrossRef]

29. Norton, T.A.; Zacher, H.; Ashkanasy, N.M. Organisational sustainability policies and employee green behaviour: The mediating role of work climate perceptions. J. Environ. Psychol. 2014, 38, 49-54. [CrossRef]

30. Schneider, B. Organizational Climate and Culture; Jossey-Bass: San Francisco, CA, USA, 1990.

31. Schneider, B.; Ehrhart, M.G.; Macey, W.H. Organizational climate and culture. Annu. Rev. Psychol. 2013, 64, 361-388. [CrossRef]

32. Norton, T.; Zacher, H.; Ashkanasy, N. On the importance of pro-environmental organizational climate for employee green behavior. Ind. Organ. Psychol. 2012, 5, 497-500. [CrossRef]

33. Magill, M.S.; Yost, P.R.; Chighizola, B.; Stark, A. Organizational climate for climate sustainability. Consult. Psychol. J. 2020, 72, 198-222. [CrossRef]

34. Zientara, P.; Zamojska, A. Green organizational climates and employee pro-environmental behaviour in the hotel industry. J. Sustain. Tour. 2018, 26, 1142-1159. [CrossRef]

35. Yuriev, A.; Boiral, O.; Guillaumie, L. Evaluating determinants of employees' pro-environmental behavioral intentions. Int. J. Manpow. 2020, 41, 1005-1019. [CrossRef]

36. McDonald, R.I.; Fielding, K.S.; Louis, W.R. Conflicting norms highlight the need for action. Environ. Behav. 2014, 46, 139-162. [CrossRef]

37. Smyth, L.; Chandra, V.; Mavor, K.I. Social identification and normative conflict: When student and educator learning norms collide. J. Appl. Psychol. 2018, 48, 293-303. [CrossRef]

38. McDonald, R.I.; Fielding, K.S.; Louis, W.R. Conflicting social norms and community conservation compliance. J. Nat. Conserv. 2014, 22, 212-216. [CrossRef]

39. Mouro, C.; Castro, P. Talking in defense of species conservation: The role of laws and community norms conflicts across stages of a communicative action. Psyecology 2017, 8, 354-374. [CrossRef]

40. Conner, M.; Sparks, P. Ambivalence and attitudes. Eur. Rev. Soc. Psychol. 2002, 12, 37-70. [CrossRef]

41. Priester, J.R.; Petty, R.E. The gradual threshold model of ambivalence: Relating the positive and negative bases of attitudes to subjective ambivalence. J. Personal. Soc. Psychol. 1996, 71, 431-449. [CrossRef]

42. Scott, W.A. Cognitive consistency, response reinforcement, and attitude change. Sociometry 1959, 22, 219-229. [CrossRef]

43. Conner, M.; Armitage, C.J. Attitudinal ambivalence. In Attitudes and Attitude Change; Crano, W., Prislin, R., Eds.; Psychology Press: New York, NY, USA, 2008; pp. 261-286.

44. Van Harreveld, F.; Nohlen, H.U.; Schneider, I.K. The ABC of ambivalence: Affective, behavioral, and cognitive consequences of attitudinal conflict. Adv. Exp. Soc. Psychol. 2015, 52, 285-324. [CrossRef]

45. Castro, P.; Garrido, M.; Reis, E.; Menezes, J. Ambivalence and conservation behaviour: An exploratory study on the recycling of metal cans. J. Environ. Psychol. 2009, 29, 24-33. [CrossRef] 
46. Van Harreveld, F.; van der Pligt, J.; De Vries, N.K.; Wenneker, C.; Verhue, D. Ambivalence and information integration in attitudinal judgment. Br. J. Soc. Psychol. 2004, 43, 431-447. [CrossRef] [PubMed]

47. Rothman, N.B.; Pratt, M.G.; Rees, L.; Vogus, T.J. Understanding the dual nature of ambivalence: Why and when ambivalence leads to good and bad outcomes. Acad. Manag. Ann. 2017, 11, 33-72. [CrossRef]

48. Sawicki, V.; Wegener, D.T.; Clark, J.K.; Fabrigar, L.R.; Smith, S.M.; Durso, G.R.O. Feeling conflicted and seeking information: When ambivalence enhances and diminishes selective exposure to attitude-consistent information. Personal. Soc. Psychol. Bull. 2013, 39, 735-747. [CrossRef]

49. Cavazza, N.; Serpe, A. Effects of safety climate on safety norm violations: Exploring the mediating role of attitudinal ambivalence toward personal protective equipment. J. Saf. Res. 2009, 40, 277-283. [CrossRef]

50. Mouro, C.; Castro, P. Self-other relations in biodiversity conservation in the community: Representational processes and adjustment to new actions. J. Community Appl. Soc. 2016, 26, 340-353. [CrossRef]

51. Lim, J.H.; Tai, K.; Kouchaki, M. Ambivalent bosses: An examination of supervisor expressed emotional ambivalence on subordinate task engagement. Organ. Behav. 2021, 165, 139-152. [CrossRef]

52. Liang, H.; Lin, K.-Y.; Zhang, S.; Su, Y. The impact of coworkers' safety violations on an individual worker: A social contagion effect within the construction crew. Int. J. Environ. Res. Public Health 2018, 15, 773. [CrossRef]

53. Ashforth, B.E.; Rogers, K.M.; Pratt, M.G.; Pradies, C. Ambivalence in organizations: A multilevel approach. Organ. Sci. 2014, 25, 1453-1478. [CrossRef]

54. Schuh, S.C.; Van Quaquebeke, N.; Göritz, A.S.; Xin, K.R.; De Cremer, D.; Van Dick, R. Mixed feelings, mixed blessing? How ambivalence in organizational identification relates to employees' regulatory focus and citizenship behaviors. Hum. Relat. 2016, 69, 2224-2249. [CrossRef]

55. Ciampa, V.; Sirowatka, M.; Schuh, S.C.; Fraccaroli, F.; van Dick, R. Ambivalent identification as a moderator of the link between organizational identification and counterproductive work behaviors. J. Bus. Ethics 2021, 169, 119-134. [CrossRef]

56. Priester, J.R.; Petty, R.E. Extending the bases of subjective attitudinal ambivalence: Interpersonal and intrapersonal antecedents of evaluative tension. J. Personal. Soc. Psychol. 2001, 80, 19-34. [CrossRef]

57. Kristof, A.L. Person organization fit: Integrative review of its conceptualizations, measurement, and implications. Pers. Psychol. 1996, 49, 1-49. [CrossRef]

58. Lu, H.; Liu, X.; Chen, H.; Long, R. Employee-organization pro-environmental values fit and pro-environmental behavior: The role of supervisors' personal values. Sci. Eng. Ethics 2019, 25, 519-557. [CrossRef]

59. Faul, F.; Erdfelder, E.; Buchner, A.; Lang, A.G. Statistical power analyses using G* Power 3.1: Tests for correlation and regression analyses. Behav. Res. Method. 2009, 41, 1149-1160. [CrossRef]

60. Duarte, A.P. Corporate Social Responsibility from an Employee's Perspective: Contributions to Understanding Job Attitudes. Ph.D. Thesis, ISCTE Instituto Universitário de Lisboa, Lisbon, Portugal, 2011.

61. Turker, D. Measuring corporate social responsibility: A scale development study. J. Bus. Ethics 2009, 85, 411-427. [CrossRef]

62. Poortinga, W.; Pidgeon, N. Exploring the structure of attitudes toward genetically modified food. Risk Anal. 2006, 26, 1707-1719. [CrossRef]

63. Greaves, M.; Zibarras, L.D.; Stride, C. Using the theory of planned behavior to explore environmental behavioral intentions in the workplace. J. Environ. Psychol. 2013, 34, 109-120. [CrossRef]

64. Robertson, J.L.; Barling, J. Greening organizations through leaders' influence on employees' pro-environmental behaviors. J. Organ. Behav. 2012, 34, 176-194. [CrossRef]

65. Podsakoff, P.M.; MacKenzie, S.B.; Lee, J.Y.; Podsakoff, N.P. Common method biases in behavioral research: A critical review of the literature and recommended remedies. J. Appl. Psychol. 2003, 88, 879. [CrossRef]

66. Hayes, A.F. Introduction to Mediation, Moderation and Conditional Process Analysis, 2nd ed.; Guilford Press: New York, NY, USA, 2018.

67. Cohen, J.; Cohen, P.; West, S.G.; Aiken, L.S. Applied Multiple Regression/Correlation Analysis for the Behavioral Sciences; Routledge: Abingdon-on-Thames, UK, 2003.

68. Montgomery, D.; Peck, E. Introduction to Linear Regression Analysis; John Wiley \& Sons: New York, NY, USA, 1982.

69. Chaudhary, R. Green human resource management and employee green behavior: An empirical analysis. Corp. Soc. Responsib. Environ. Manag. 2020, 27, 630-641. [CrossRef]

70. He, J.; Morrison, A.M.; Zhang, H. Being sustainable: The three-way interactive effects of CSR, green human resource management, and responsible leadership on employee green behavior and task performance. Corp. Soc. Responsib. Environ. Manag. 2021, 28, 1043-1054. [CrossRef]

71. Milfont, T.L. The effects of social desirability on self-reported environmental attitudes and ecological behaviour. Environ. 2009, 29, 263-269. [CrossRef]

72. Homburg, A.; Stolberg, A. Explaining pro-environmental behavior with a cognitive theory of stress. J. Environ. Psychol. 2006, 26, 1-14. [CrossRef]

73. Francoeur, V.; Paillé, P.; Yuriev, A.; Boiral, O. The measurement of green workplace behaviors: A systematic review. Organ. Environ. 2021, 34, 18-42. [CrossRef]

74. Dixon, G.N.; Deline, M.B.; McComas, K.; Chambliss, L.; Hoffman, M. Using comparative feedback to influence workplace energy conservation: A case study of a university campaign. Environ. Behav. 2014, 47, 667-693. [CrossRef] 
75. Boiral, O.; Talbot, D.; Paillé, P. Leading by example: A model of organizational citizenship behavior for the environment. Bus. Strategy Environ. 2015, 24, 532-550. [CrossRef]

76. Cavazza, N.; Butera, F. Bending without breaking: Examining the role of attitudinal ambivalence in resisting persuasive communication. Eur. J. Soc. Psychol. 2008, 38, 1-15. [CrossRef]

77. Pillaud, V.; Cavazza, N.; Butera, F. The social value of being ambivalent: Self-presentational concerns in the expression of attitudinal ambivalence. Personal. Soc. Psychol. Bull. 2013, 39, 1139-1151. [CrossRef]

78. Pillaud, V.; Cavazza, N.; Butera, F. The social utility of ambivalence: Being ambivalent on controversial issues is recognized as competence. Front. Psychol. 2018, 9, 961. [CrossRef]

79. Turker, D. How corporate social responsibility influences organizational commitment. J. Bus. Ethics 2009, 89, 189-204. [CrossRef] 